\title{
First record of Hippa admirabilis Thallwitz, 1891 (Crustacea: Decapoda: Hippidae) from Tomini Bay, Province Gorontalo, Indonesia confirmed by DNA barcoding
}

\author{
Vinna Windy Putri $^{1}$, Fahri Fahri ${ }^{2}$, Yusli Wardiatno ${ }^{3,4}$, Achmad Farajallah ${ }^{1 *}$ \\ ${ }^{1}$ D epartment of Biology, Faculty of M athematics and Natural Sciences, IPB University, K ampus IPB Dramaga, B ogor 16680, \\ Indonesia \\ 2D epartment of Biology, Faculty of M athematics and Natural Sciences, Jalan Soekarno-Hatta, Tondo, Palu, 94117, Central \\ Sulawesi, Indonesia \\ ${ }^{3}$ D epartment of A quatic R esources M anagement, Faculty of Fisheries and M arine Sciences, IPB University, Kampus IPB Dramaga, \\ Bogor 16680, Indonesia \\ ${ }^{4}$ Environmental Research Center, IPB University, K ampus IPB Dramaga, Bogor 16680, Indonesia
}

\begin{abstract}
Hippoid crab is a crustacean group which inhabits sandy beach in tropical and subtropical areas. There are seven species of hippoid crab has been reported from Indonesia so far, i.e. six from family Hippidae and one from family A lbuneidae. One of them is Hippa admirabilis Thal wittz, 1891. This species is first record from Tomini Bay, province in our study. The Specimens were collected from Tomini Bay in 2016. To confirm the species, we used CO1 gene as DNA barcoding. The DNA was extracted from the muscle tissues. The upper part of $\mathrm{CO} 1$ gene was amplified using Primer AF 215-216. The CO1 gene that we retrieved was $634 \mathrm{bp}$. The samples from our study have about $99.8 \%$ similarity with the sequence of Hippa admirabilis in Genebank with the accession number is K R047031.1. Based on morphological and molecular data, our samples are confirmed as $H$. admirabilis.
\end{abstract}

\section{Introduction}

Species from superfamily Hippoidea usually has small size. These species inhabits sandy area. The animal of this superfamily can be found in tropical and subtropical zones [1]. There are three families of hippoid crab, i.e Albuneidae Stimpson, 1858, Hippidae Latreille, 1825, year and Blepharipodidae Boyko, 2002. Only two families have been reported so far in Indonesia, Hippidae and Albuneidae. They inhabit different zones of beach area. Hippidae lives in intertidal zone. Intertidal zone is the area that is above water at low tide and underwater at high tide depth. Albuneidae lives in sublittoral zone. Sublitoral zone is the sea-shore zone lying immediately below the littoral (intertidal) zone and extending to about $200 \mathrm{~m}$ depth. The Family Hippidae in Indonesia is comprises of seven species, i.e. Hippa adactyla, Hippa ovalis, Hippa marmorata, Hippa celaeno, Hippa admirabilis, and Emerita emeritus.

Distribution of the Family Hippidae is ranging from West to East Indonesia. Hippa adactyla is distributed in Sumatera, Java, Bali and West Nusa Tenggara. Emerita emeritus distributed in Sumatera and Java. Hippa ovalis is distributed in Sulawesi. Hippa marmorata is distributed in West Nusa Tenggara, Sulawesi and
Southeast Maluku [2]. Hippa admirabilis is distributed in Sulawesi.

Hippa admirabilis was firstly reported from Papua New Guinea. Hippa admirabilis was previously recorded from Central Sulawesi (Talise Beach, Lero, Banggai) and Southeast Sulawesi (Buton) [2]. This species was also found in Taiwan [1]. This species inhabits sandy area and intertidal area. Previously, there was no record of this species in Tomini bay. To date, there is only one data of Hippa admirabilis $\mathrm{CO} 1$ gene in Genbank with the accession number is KR047031.1. Our study aims to report the presence of species Hippa admirabilis Tomini Bay, Sulawesi.

\section{Material and Methods}

\subsection{Sample collection and identification}

Twelve specimens were collected from Tomini Bay area on July, 2016. The samples were preserved and stored using $96 \%$ ethanol. The species was identified with identification key literatures $[1,3]$ based on their morphological characters.

\footnotetext{
* Corresponding author: achamadfarajallah@gmail.com
} 
Table 1. The top one BLAST-N of representative specimen of $H$. admirabilis $\mathrm{CO} 1$ gene sequences

\begin{tabular}{|c|c|c|c|c|c|c|c|}
\hline No & Sequence name & Top 1 BLAST-N & $\begin{array}{l}\text { Query } \\
\text { Cover }\end{array}$ & e-value & Identity & $\begin{array}{l}\text { Accession } \\
\text { number }\end{array}$ & Reference \\
\hline 1 & 3364944_Tomini1 & H. admirabilis & $97 \%$ & 0.0 & $99.70 \%$ & $\underline{\text { KR047031.1 }}$ & Wardiatno et al. [2] \\
\hline 2 & 3364910_Tomini3 & H. admirabilis & $96 \%$ & 0.0 & $99.85 \%$ & $\underline{\text { KR047031.1 }}$ & \\
\hline 3 & 3364914_Tomini8 & H. admirabilis & $97 \%$ & 0.0 & $99.85 \%$ & $\underline{\text { KR047031.1 }}$ & \\
\hline
\end{tabular}

\subsection{DNA Analysis}

DNA was extracted from muscle tissue of $H$. admirabilis. The DNA extraction was performed using Geneaid Genomic DNA Mini Kit (Tissue). We used Primer Forward AF215 and Primer Reverse AF216 to amplify the upper part of Cytochrome c oxidase 1. The PCR condition were set according to Wardiatno [2]. To make sure that the DNA target was successfully amplified, we conducted electrophoresis in Polyacrylamide gel $6 \%$. The gel then visualised using silver staining method [4]. The successful amplicon is sequenced to obtain the sequence data. The chromatogram and sequences were analysed using MEGA 7 [5]. The CO1 gene sequences were aligned for further analysis. These procedures were conducted in Animal Molecular Laboratory, Division of Animal Function and Behavior, Department of Biology, Faculty of Mathematics and Natural Sciences, IPB University.

\section{Results and Discussion}

\subsection{Identification based on morphological character}

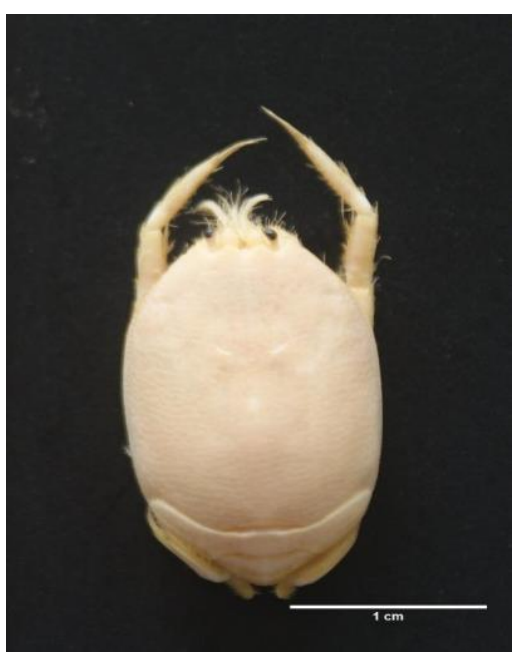

Fig. 1. Hippa admirabilis specimen.
The identification was conducted following Boyko and Harvey [3] and Osawa et al. [1]. The characters we examined for identification were carapace and pereiopod The carapace is longer than wide. Frontal margin of carapace has two median lobes which is separated by small rounded lobe. The lateral lobe of carapace exceeds median lobe. The antennal flagellum consists of 1-2 articles. The pereiopod II and III is slightly concave on dorsal margin. These characters are identical to Hippa admirabilis (Figure 1) characters as in literatures we used for identification. Hippa admirabilis is mostly similar with Hippa adactyla Fabricius, 1787. The similar features are: the frontal margin has three median lobe, and the lateral lobes exceeded median lobes. Hippa admirabilis differ from Hippa adactyla in the anterior lateral angle of carapace and the shape of pereiopod II and III.

\subsection{Systematics}

Infraorder ANOMURA Macleay, 1838

Family HIPPIDAE Stimpson, 1858

Genus Hippa Fabricius, 1787

Hippa admirabilis (Thallwitz, 1891)

\subsection{Identification based on DNA barcoding}

We obtained $634 \mathrm{bp}$ of $\mathrm{CO} 1$ gene from three specimens of $H$. admirabilis from Tomini Bay. Our samples are 99.8\% similar with sequence of Hippa admirabilis in Genbank with accession number KR047031.1. (Tabel 1). This result is consistent with the morphological data.

We used Hippa adactyla and Hippa ovalis as ingroup reference and Emerita emeritus as outgroup from the same family, Hippidae, to construct the phylogenetic tree (Figure 2). The topography of $H$. admirabilis gene tree that we had constructed is similar to Wardiatno et al. (2015) which shows Hippa admirabilis and Hippa adactyla are in the same group. This result was also supported by morphological characters which were described by Osawa et al. [1] who showed the morphology of $H$. admirabilis was similar to $H$. adactyla. 


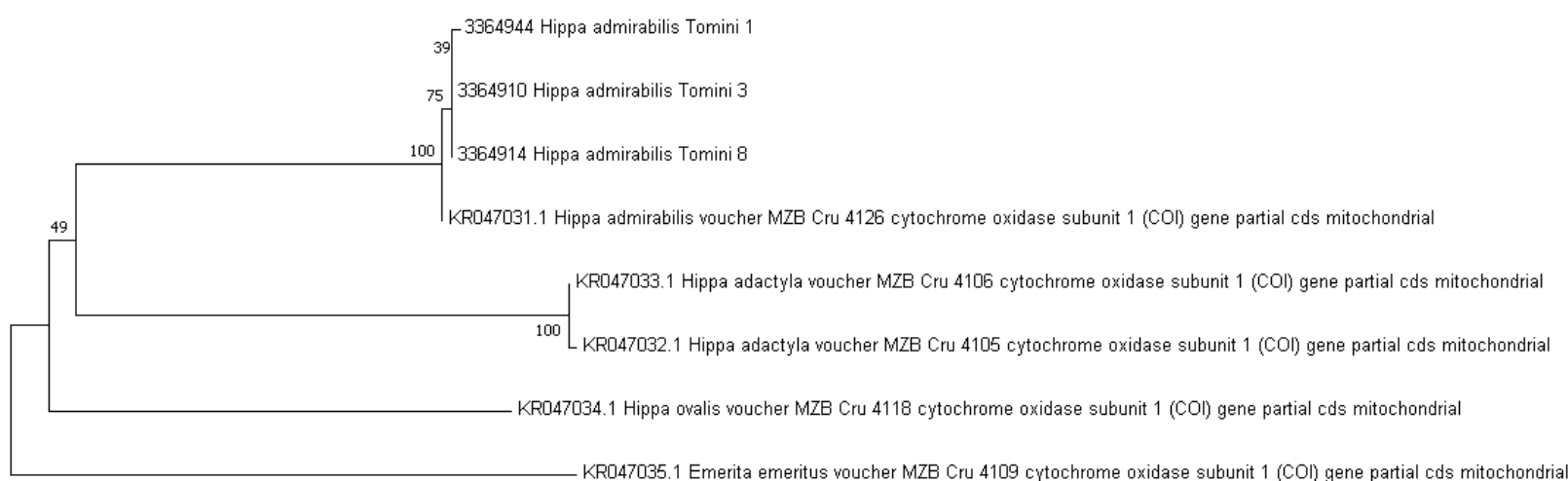

0.020

Fig. 2. Gene Tree using Neighbor-Joining Method

Hippa admirabilis was previously recorded from Indonesia in Central Sulawesi (Talise Beach, Lero, Banggai) and Southeast Sulawesi (Buton) [2]. This species was also found in Taiwan, which also located in Indo West Pacific and have tropical climate. It is very likely that $\mathrm{H}$. admirabilis distribution might be affected by sea currents and also biological factors.

\section{Conclusion}

Our finding added report of Hippa admirabilis to Crustacean distribution list in Indonesia.

I would like to thank Ministry of Research and Higher

Education for the grant of PMDSU no. 3/E1/KP.PTNBH 2019.

\section{References}

1. M. Osawa, C.B. Boyko, T.Y. Chan, Crustacean fauna of Taiwan: crab-like anomurans (Hippoidea, Lithodoidea and Porcellanidae) (National Taiwan University, Keelung, 2010)

2. Y. Wardiatno, P.U. Ardika, A. Farajallah, N.A. Butet, A. Mashar, M.M. Kamal, M.A. Sarong, AACL Bioflux 8(2):224-235 (2015)

3. C.B. Boyko, A.W. Harvey, Résultats des campagnes MUSORSTOM 20, 379-406 (1999)

4. S.O. Byun, Q. Fang, H. Zhou, J.G.H. Hickford, Anal. Biochem. 385(1), 174-175 (2009)

5. S. Kumar, G. Stecher, K. Tamura, Mol. Biol. Evol 33(7), 1870-1874. (2016) 